\title{
Factors Causing students' Inhibition in English Speaking Performance
}

\author{
Tran Thi Trang Loan ${ }^{1 *}$, Le Van Tuyen ${ }^{2}$ \\ ${ }^{l}$ English lecturer at Ho Chi Minh City University of Food Industry (HUFI)-Vietnam \\ ${ }^{2}$ English lecturer at Ho Chi Minh City University of Technology (HUTECH)-Vietnam \\ *Corresponding Authors: Tran Thi Trang Loan, Ho Chi Minh City University of Food Industry \\ (HUFI)-Vietnam
}

\begin{abstract}
Speaking English is very challenging for most Vietnamese undergraduate students. One of the problems they have to face is inhibition which prevents them from speaking. This study therefore aims to explore factors that cause inhibition in English speaking performance among students and discover teachers' and students' role in reducing inhibition in speaking. The study was conducted at Ho Chi Minh City University of Food Industry (HUFI)-Vietnam with the participation of 121 English majored students and 4native English speaking teachers (NEST). Two instruments were employed to collect both quantitative and qualitative data, namely the questionnaire and interview. The findings of the study revealed that the factors that caused inhibition in speaking performance among students were not only related to the students themselves, but also to the teachers as well. To reduce inhibition, the participants also reported that both teachers and students should do different tasks or find ways to reduce inhibition both inside and outside the class during the process of learning English speaking skills. It is expected that the study will partly contribute to the enhancement of the teaching and learning English speaking skills of English majored students at HUFI in particular and at the Vietnamese tertiary level in general.
\end{abstract}

Keywords: undergraduate students, inhibition, speaking performance, roles, Vietnamese tertiary level

\section{INTRODUCTION}

English language students often need to be able to speak with confidence .n order to carry out many of their most basic transactions (By gate, 1987). In addition, Baker and West up (2003) stated, speaking is of vital importance outside the classroom; students who speak English well can have a greater chance for better education, finding good jobs and getting promotions. Nevertheless, according to Brown and Yule (1983), oral language production is often considered one of the most difficult aspects of language learning. Speaking represents a real challenge to most EFL students. In EFL contexts, they usually face difficulties in using English in the classroom -the only place for them to acquire this language especially when it comes to speaking skills. The issue is getting deservedly intentional to undergraduate students who are supposed to become the key manpower of every country. Many of them have problems in English speaking; and many factors may affect their performance. One of the affective variables may be inhibition among students. Inhibition is considered as a negative feeling which can hinder the presentation of a person in different situations.

Speaking is a productive skill which deserves attention every bit as much as literary skills both in first and second languages (By gate, 1987). That is why recently, "inhibition" term in English speaking performance has become a concerned and debated matter, and received extensive research among language teachers, linguists and researchers such as Abedini and Chalak (2017).

Although investigations have begun to shed light on factors causing inhibition in speaking performance of students, few studies on inhibition have been conducted at the Vietnamese tertiary level so far. Furthermore, no literature has been found at HUFI in terms of non-English majored students' inhibition in English speaking performance. For the above-mentioned reasons, it is believed that there is an urgent need to examine this construct, especially in the context of HUFI. Therefore, the current study aims at gaining some insights into inhibition in speaking performance among 
Vietnamese students. More specifically, (a) it attempts to investigate the factors that may cause inhibition among second year non- English majored tertiary students at HUFI; and (b) explore what teachers and students should do to reduce students' inhibition in English speaking performance at HUFI.

The study is expected to raise students' and teachers' awareness of the negative effects of inhibition on students' speaking performance and give recommendations that may be of great help for both teachers and students to overcome inhibition in English speaking performance at HUEI in particular and at the Vietnamese tertiary in general.

The study attempted to address the two following research questions:

1. What are the factors that cause English majored students' inhibition in English speaking performance?

2. What should teachers and students do to reduce students' inhibition in English speaking performance?

\section{BRIEF LITERATURE REVIEW}

\subsection{Inhibition and Factors Causing Inhibition in Speaking Performance}

Inhibition is considered as a negative factor that hinders students from their natural performance and makes them act in a reluctant, hesitant or anxious way (Richards \& Schmidt, 2002). It can be understood that inhibition may make students be afraid of using English. They always feel embarrassed whenever they speak English. Instead of taking risks in learning, they are reluctant to speak English. Researchers have discovered various factors that cause inhibition in English speaking performance among EFL students. Those factors are related to both students and teachers. Students' language knowledge and psychology certainly affect their speaking performance.

Firstly, concerning factors related to language knowledge. Without mastering grammatical rules and having adequate vocabulary as well as pronouncing words correctly, EFL students are usually afraid of speaking. Vocabulary is recognized as an important component of L2 performance and proficiency (Schmitt, 2010). It plays an important role in oral communication (Cook, 2013).Lack of vocabulary knowledge hinders the real communication of EFL students to a great extent (Adam, 2016). In addition, to produce accurate information and meaningful communication, pronunciation plays the part (Kelly, 2000). Students' difficulty in pronouncing the words will affect their oral performance because they are afraid of mispronouncing the words and that in turn hinder them from speaking confidently (Brown, 2000).

Secondly, regarding affective factors such as 'anxiety' which is considered as the subjective feelings of tension, apprehension, nervousness, and worry associated with an arousal of the autonomic nervous system (Spielberger, 2013). It is said that students who experience anxiety will not be able to focus on the speaking process; another factor is 'self-esteem'. As Brown (1994) noted, inhibition is intertwined with self-esteem and anxiety. Lightbown and Spada (2003) also believed that the concept of selfesteem is closely related to the notion of inhibition. In addition, shyness, lack of motivation and lack of self-confidence also affect students' speaking performance.

Last but not least, factors related to teachers such as their teaching and assessment methods or attitudes may motivate or demotivate their students in learning. For example, although assessment and corrections are necessary, for many students, they are demotivating factors that may produce their inhibition in language learning activity. According to Harmer (1991) students can find this very demotivating and become afraid to speak if they are corrected all the time; and Cohen (2001) also stated that students consider language assessment as a threat to their oral performance because they are afraid of being inadequate in language ability.

\subsection{Strategies used by Teachers and Students in Reducing Students' Speaking Inhibition}

Reducing inhibition in English speaking performance is not easy. This task is still a great challenge for teachers and students in the EFL classroom. It requires them to play an active role in the process of teaching and learning EFL as stated by Dörnyei and Kubanyiova (2014) that both teachers and students play essential roles in eliminating students' inhibition as well as the barriers of being passive. So far, there has been a lot of research conducted, which suggests possible ways for both teachers and students to overcome students' inhibition in speaking classrooms. 
Firstly, for teachers, to help their students feel free to talk, they need to employ their roles in teaching process to create a positive, supportive and relaxing learning environment which may help lower students' anxiety, increase their confidence, and encourage their willingness to communicate, or establish good rapport between teachers and students. Kubo (2009) added that to build students' confidence to speak English, teachers can provide regular opportunities to practice proper pronunciation and intonation, and to converse freely. In addition, teachers need to help students establish positive attitudes towards speaking errors (Truscott \& Hsu, 2008), which supports them in acquiring the English language more easily.

Secondly, for students, along with the teacher's role and tasks, it is of vital importance for students to find ways to eliminate inhibition. They need to follow learning strategies (Oxford, 2003). They should break barriers of psychology by arranging to work with their peers (Dornyei, 2013). In addition, they need to create motivation, take risks in their learning (Brown, 2002).Through the participation in different tasks, students gradually reduce their anxiety or shyness in learning.

In conclusion, both teachers and students should take the initiative, play an active role and do different tasks in reducing inhibition in English speaking performance among EFL students.

\section{RESEARCH METHODS}

\subsection{Participants}

The study was conducted at HUFI in Ho Chi Minh City-Vietnam with the participation oftwo cohorts, namely English majored students and English teachers coming from the faculty of Foreign Language.

The first cohort consisted of 4NESTs who were teaching English speaking classes at HUFI. They have different experience in teaching students in this university. Two of them are male, and the other two are female. Their ages range from 33 to 40; and their teaching experience ranges from 5 to 15 years. The second cohort was comprised of 121 second- and third-year English - majored students who were learning speaking skills. 41 of them are male; and 80 of them are female. Their ages range from 19-21.

\subsection{Research Instruments}

The study employed two major instruments for collecting data, namely the questionnaire for quantitative data and interview for qualitative data. The questionnaire was designed to survey the student participants. It consisted of two parts; part one asked about the demographic information of the participants and part two consisted of 23 items asking about factors causing inhibition in speaking performance. The questionnaire was adapted from Abedini and Chalak (2017). All of the items of the questionnaire were specially designed according to 5-point Likert scale ranging from 1-Never true, 2 Rarely true, 3- Sometimes true, 4-Often true and 5-Always true. Interview questions were designed for both teacher and student participants. All the questions ask about factors causing speaking inhibition among students and roles of teachers and students in reducing inhibition in speaking performance.

\subsection{Data Collection and Analysis Procedures}

Data collection for the study was carried out from October to December 2019. The survey and interviews were conducted in UEI campus. To conduct the student questionnaire survey, the researcher came to each class, told the students about the purpose of the study and instructed them how to complete the questionnaire, 140 questionnaire copies were administered to the students, but after 2 days 132 copies were returned and 121 copies were correctly and validly completed (86\%). Among 121 students, 8 of them were invited to participate in the interview. In order to access to the teacher participants to conduct the interviews, the researcher phoned them and asked for permission to conduct the interview with them. 4 of them agreed to participate in the interview during break time.

Regarding data analysis procedures, for analyzing quantitative data collected from the questionnaire, descriptive statistics was employed through the use of SPSS version 22. Mean scores and standard deviation were calculated. Based on calculated interval coefficient for four intervals in five points (5$1=4)$, intervals with the range of $0.80(4 / 5)$ were arranged. The following criteria in the Likert type scale were used to interpret the data: never true $(1.00-1.80)$; rarely true $(1.81-2.60)$; sometimes true (2.61 - 3.40); often true (3.41 - 4.20); always true (4.21 - 5.00). For qualitative data collected from interviews, "content analysis" was employed. The responses gathered from the interviews were categorized into the themes so that factors causing inhibition in speaking performance and what 
teachers and students should do to reduce inhibition were presented and interpreted. The students were coded as S1 to S8; and the teachers were coded as T1 to T4.

Regarding reliability and validity of the study, the questionnaire was piloted. It was done with 20 students from 1 class. Some revision for the final questionnaire was made. Cronbach's Alpha indexes were calculated. The results were .721 for 23 items used to measure students' perceptions of the factors causing their inhibition in speaking performance.

\section{RESUltS OF THE STUDY}

\subsection{Factors Causing Inhibition in English Speaking Performance}

Research question 1 aimed to explore factors causing inhibition in speaking performance among second and third-year English-majored students at HUFI. The data collected from two instruments are displayed below. Quantitative data are combined with qualitative data to obtain triangulation.

\subsubsection{Student-Related Factors}

\section{Language Knowledge}

Table1. Language knowledge factors causing inhibition in English speaking performance $(N=121)$

\begin{tabular}{|l|l|l|l|}
\hline No & Factors related to language knowledge & M & St.D \\
\hline 1 & I don't know what to talk about. & 3.42 & 1.02 \\
\hline 2 & I am not knowledgeable enough to talk freely. & 3.41 & .897 \\
\hline 3 & I am afraid of making mistakes and this keeps me away from speaking. & 3.36 & .953 \\
\hline 4 & I don't have enough vocabulary knowledge to express myself. & 3.54 & .774 \\
\hline 5 & English grammar rules make me overwhelmed. & 3.76 & .784 \\
\hline 6 & I can only answer questions rather being able to talk freely. & 3.23 & .583 \\
\hline 7 & I feel embarrassed about my pronunciation and accent. & 3.12 & .930 \\
\hline 8 & My pronunciation is not very good in comparison with my classmates. & 3.00 & .655 \\
\hline 9 & I don't think I have the aptitude or gift to learn a new language. & 2.93 & .553 \\
\hline
\end{tabular}

As displayed in table 1, the results revealed that more or less linguistic factors are closely related to the occurrence of inhibition in speaking performance among students. It can be seen that according to the students, four factors were often true to them, which means they are the factors that often caused inhibition in speaking performance. Accordingly, the students reported that they did not know what to talk about (item 1); they were not knowledgeable enough to talk freely (item 2); they did not have enough vocabulary knowledge to express themselves (item 4); and they thought that English grammar rules made them overwhelmed (item 5) with $\mathrm{M}=3.42,3.41,3.54, \& 3.76$ respectively.

Regarding the other factors displayed in Table 1, the data show that they sometimes cause inhibition among students. More specifically, the students agreed that they were sometimes afraid of making mistakes, which kept them away from speaking (item 3) with $\mathrm{M}=3.36$ and St. $\mathrm{D}=.953$; or they could only answer questions rather being able to talk freely (item 6) with $\mathrm{M}=3.23$ and $\mathrm{St}$. $\mathrm{D}=.58$; besides, they also reported that they sometimes felt embarrassed about their pronunciation and accent (item 7) with $\mathrm{M}=3.12$ and St. $\mathrm{D}=.930$. They also thought that their not-very-good pronunciation in comparison with classmates might sometimes cause inhibition (item 8) with $\mathrm{M}=3.00$ \& St. D $=.655$. However, very few of them thought that they did not have the aptitude or gift to learn a new language (item 9) with $\mathrm{M}=2.93 \&$ St. $\mathrm{D}=0.553$, which means that most of them were really confident that they could learn English although difficulties could not be avoided.

Regarding qualitative data collected from the interviews, most of the students reported that several factors that caused inhibition in speaking performance are related to linguistics. Among 8 student interviewees, 7 of them said that lack of vocabulary and complication of English grammar prevented them from speaking. Sometimes they did not dare to speak because they could not find exact words for expressing their ideas. For example S3 reported, "I do not have enough vocabulary to talk or to answer teacher's question, and therefore I am rather passive in classroom, especially in speaking sections", or S7 expressed, "The most challenge to me in speaking is how to use the right words and grammar. I don't think I speak correct English so sometimes I don't dare to speak in front of class or to a foreigner."

In terms of data collected from the teacher interviews, all the 4 teachers reported that the factors that caused inhibition in speaking performance among students were pronunciation. They said that most of 
the students did not pronounce English words correctly. Consequently, they were not actively involved in free conversations with teachers or friends. For example T1 said, "I'm a native English teacher. My students in this class go to school regularly. However, many of them are not very confident in speaking English. As observed I find that they lack vocabulary. They sometimes make mistakes in grammar and pronunciation. I always tell them not to be afraid of making mistakes, try to speak anytime, but it seems what I tell them doesn't work."

In conclusion, based on the findings of the study it can be confirmed that although the students have different opinions, 9 linguistic factors displayed in Table 1 caused inhibition in English speaking performance among English-majored students.

\section{Affective Factors}

Table2. Affective factors causing inhibition in learning English speaking skills $(N=121)$

\begin{tabular}{|l|l|c|c|}
\hline No & Affective factors & M & St.D \\
\hline 1 & I don't have enough confidence to start a talk or ask a question. & 3.41 & .933 \\
\hline 2 & I am a shy person and I usually talk little either in Vietnamese or English. & 3.35 & .846 \\
\hline 3 & $\begin{array}{l}\text { I lose concentration when I start talking because of too many things needed to be } \\
\text { focused on. }\end{array}$ & 3.47 & .729 \\
\hline 4 & I am a nervous person, which has effects on my participation in class. & 3.07 & .955 \\
\hline 5 & I am always anxious while I am in the classroom. & 2.85 & .964 \\
\hline 6 & I expect too much of myself, which keeps me away from speaking. & 2.59 & .861 \\
\hline
\end{tabular}

As illustrated in Table 2, the students' inhibition in learning speaking skills was also caused by a set of affective factors at two different frequencies from "sometimes" to "often". Firstly, in regards to confidence, the students said that they did not have enough confidence to start a talk or ask a question (item 1) with $\mathrm{M}=3.41 \& \mathrm{St}$. $\mathrm{D}=.933$. Obviously, lack of confidence might become a key indicator in drawing them into inhibited state. Another factor that might often prevent the students from speaking is loss of concentration when talking to others because of many things needed to be focused on at the same time (item 3) with $\mathrm{M}=3.47 \&$ St. $\mathrm{D}=.729$.

The next three factors which sometimes caused inhibition are students' shy, nervous and anxious states (items $2,4, \& 5$ ) with $\mathrm{M}=3.35,3.07 \& 2.85$ and $\mathrm{St}$. $\mathrm{D}=.846, .955 \& .964$ respectively. The only one factor that rarely caused inhibition among students is item 6 that shows that the students did not expect too much of themselves (item 6) with $\mathrm{M}=2.59$ and St. $\mathrm{D}=.861$.

Regarding data collected from the interviews, it was found that among 8 students, 6 of them said that they did not have sufficient confidence in communicating with others in English; even they felt anxious and reluctant to speak. For example S1 expressed, "To other lessons, I do not feel anxious, reluctant or something like that. However, when I come to speaking sections, I find that I am more inhibited and anxious. Gradually, it becomes a habit; and when I am in front of many people, I am hesitant and reluctant to talk." Having similar opinions to the students, 4 teachers also reported that many students were not confident enough to communicate in English that might because of their low English proficiency or they had little chance to speak English to native speakers. For instance, T2 expressed, "I think the students are still not very active in class. When working in groups, only few of them attempt to use English; others seem to be quiet or say very little. They are afraid of using English."

In conclusion, it can be said that the data collected from the questionnaire and interviews confirmed that more or less 6 affective factors related to students caused inhibition in speaking performance among students. Especially, lack of confidence might cause more inhibition than other affective factors. Students need more and more practice in different situations including taking risks in learning so that they can obtain more confidence in using English.

\subsubsection{Teacher-Related Factors}

Table3. Teacher-related factors causing inhibition in English speaking performance $(N=121)$

\begin{tabular}{|l|l|l|l|}
\hline No & Teacher-related factors & M & St. D \\
\hline 1 & I don't like the way the teacher corrects my mistakes. & 3.32 & .761 \\
\hline 2 & I don't like to be negatively evaluated by the teacher. & 4.09 & .905 \\
\hline 3 & The teacher's knowledge and proficiency demotivateme in learning speaking. & 2.51 & .961 \\
\hline
\end{tabular}




\begin{tabular}{|l|l|l|l|}
\hline 4 & I always feel pressured by the teacher. & 2.83 & 1.09 \\
\hline 5 & I don't like the teacher's teaching method. It demotivates me. & 2.52 & .797 \\
\hline 6 & I am not happy with my teacher's attitudes towards our ability. & 2.48 & .948 \\
\hline 7 & I don't like the way the teacher organizes the class when we have a speaking task. & 2.42 & .747 \\
\hline 8 & I don't like the way the teacher tests my speaking performance. & 3.38 & .747 \\
\hline
\end{tabular}

The data displayed in Table 3 show that the factors related to teachers also caused inhibition. However, they did not cause as much inhibition as factors related to students. Among 8 factors related to the teacher, the students did not like to be negatively evaluated by the teacher most (item 2) with $\mathrm{M}=4.09$ and St. $\mathrm{D}=.905$. The other three factors that sometimes caused inhibition as stated by the students are the way the teacher corrected mistakes (item 1), pressure from the teacher (item 4), and the way the teacher tested their speaking performance (item 8) with $\mathrm{M}=3.32,2,83 \& 3,38$ and St. $\mathrm{D}=$ $.076,1.09 \& .747$ respectively. The factors that rarely caused inhibition are the teacher's knowledge and proficiency (item 3), the teacher's teaching method (item 5), the teacher's attitudes (item 6), and the way the teacher organized the class (item 7) with $\mathrm{M}=2.51,2.52,2.48 \& 2.42$ and St. $\mathrm{D}=.961$, $.797, .948 \& .747$ respectively.

Regarding the data collected from the interviews, it was found that all the student interviewees reported that they were satisfied with the teacher's teaching method but not with the way the teacher assessed their speaking performance. Sometimes the teacher's grading is not reasonable or fair. For instance, S3 said, "I like the teacher's teaching method. She always organizes pair work or group work for us to speak to each other. However, sometimes I don't think she is fair in grading the midterm test or daily speaking performance." Particularly, some students said that sometimes the teachers have negative comments on students' performance, which was demotivating. For example, S7 reported, "Students can't avoid mistakes when speaking English, but the teacher sometimes gets angry and say something negatively about the students' ability, accent and knowledge". Obviously, according to several students, the teacher sometimes made students lose face and be discouraged by negative criticism. By doing so, the teacher might prevent the students from taking part in speaking activities, volunteering to answer the teacher's questions, or doing speaking tasks.

\subsection{Teachers' and Students' Strategies in Reducing Inhibition in English Speaking Performance}

Research question 2 aimed at exploring strategies that students and teachers may employ to reduce students' inhibition in English speaking performance. To explore what teachers should do, the data were collected from 8 student interviews; and to explore what students should do, the data were collected from 4 teacher interviews.

\subsubsection{Teachers' Strategies in Reducing Inhibition in English Speaking Performance}

The data collected from the student interviews revealed that most of the students would like their teachers to support them in reducing inhibition through the application of a variety of tasks or strategies. Regarding the question what the teacher should do to help students reduce inhibition in English speaking performance, 7 out of 8 students said that teachers should select relevant tasks to students' proficiency. For example, S2 reported, "There are a variety of speaking tasks for us to practice, but not all of them are relevant to all the students in class. Teachers should choose the tasks which are interesting and suitable to the students.", or several other students raised their voice: "I think teacher can do a lot to increase and maintain the motivation of students by the types of tasks that they organize in the classroom.”(S2); and “...students are enthusiastic to speak when they realize that the topic is interesting or there is a clear objective that must be reached. Again, great care should be taken to make sure that the task is in line with the students' ability to deal with the tasks" (S4).

Another way that the students proposed was that the teachers should give more time for the students to prepare a topic before they can speak in the group or in front of the class. They also wanted their teachers to allow them to prepare the topic at home if it was difficult. Many of them did not have enough vocabulary so they thought they needed more time to prepare for the talk. For instance, S5 expressed, "In class sometimes I don't have enough time to prepare for the topic in my group so when everyone finishes speaking, I still have nothing to say. When the teacher asks the students to volunteer to speak, I don't dare to say anything." In terms of organizing the class for a speaking task, most of the interviewees thought that to increase students' confidence and motivation, students with similar proficient levels should sit together. The more able students should sit together and the less able ones should sit together so that when they talk about something the less able ones will not be afraid of 
losing face or losing turn to talk. For example, S7 expressed, "I'm a less able student. I am always afraid of speaking English to others, especially to more able students. Some of them speak very well. I'm afraid that they laugh at me when I make mistakes. I like sitting with some classmates like me."

The interviewees were also asked about the ways the teacher corrected oral mistakes. 3 of the students said that sometimes the teacher interrupted them when they were speaking. They also proposed the way the teacher should use to correct mistakes.S4 said, "The teacher should jot down the mistakes and then after the students finishes speaking, he or she will deal with the mistakes."Obviously, by doing so, the teacher may help students get more and more confident in speaking English.

Talking about teachers' attitudes, all the interviewees thought that positive attitudes towards students' mistakes, proficiency and ability are necessary to enhance students' speaking. S3 said, "Some students are sensitive about their ability and aptitudes. They always think that they can't speak English well and they are afraid of being negatively evaluated by the teacher and other students."

Along with the above-mentioned proposed strategies, all the student interviewees suggested that teachers should create a friendly and positive manner in teaching. Most of the respondents rated "friendly and loving" as the most preferred quality of a teacher. For them, a teacher should have the love of a mother to their students.

\subsubsection{Students' Strategies in Reducing Inhibition in English Speaking Performance}

To explore what strategies students should employ to reduce inhibition, 4 teachers were interviewed. The question raised to them was "What should students do to reduce inhibition in English speaking performance?" All the 4 native speaking teachers proposed different strategies that according to them students should do.

First of all, they all said that listening and speaking skills go together so if students want to be confident in speaking, they should improve their listening skills. They should practice listening to the radio, videos, tapes or other sources. For example, T1 said, "I think students should spend 1 or 2 hours a day listening to English at home. If they can listen well, they can understand other people speaking. At that time they can speak better; T4 expressed, "Yes, I think if they can't understand what other people say, they can't say anything, gradually they are afraid of raising their voice to say something."; "Watching video and movies is one of the good ways for students to entertain themselves and improve their listening. They can gain more confidence to express themselves in English." (T2)

Another strategy that the 4 teachers proposed was keeping practicing to speak English, not only in class but also at home with friends. In class students should actively participate in group or pair work. They can present the topic in their small group so that anxiety may be reduced. For instance, T3 expressed, "I usually organize pair or group work for my students to practice speaking. Instead of asking them to present the topic in front of the class, I ask them to present in their small group. I see that they are more interested in speaking."

Finally, all of the teachers reported that students needed to employ and practice different speaking learning strategies not only inside the class but also outside when communicating with foreigners; and they also need to know about communication strategies used to overcome communication difficulties such as how to negotiate meanings, how to reduce or maintain a conversation. For example, T4 expressed, "In my class, I often apply different learning strategies for my students to practice speaking, e.g. practicing pronunciation of words, asking friends to correct mistakes, or practicing interviewing each other. I also encourage them to use gestures or familiar words in communication so that they can get meaning through.”

\section{DISCUSSION}

Through the employment of the two instruments, namely the questionnaire and interview, the two research questions have been addressed. Regarding the findings of research question 1, it was found that many factors related to both teachers and students may cause students' inhibition in English speaking performance, nonetheless at different levels from low to moderate. In terms of studentrelated factors, the findings revealed that students' lack of vocabulary, grammatical structures, and 
confidence often caused inhibition; meanwhile the other factors only sometimes did. The findings of the study are consistent with those discovered by Abedini and Chalak (2017) that showed that factors related to both language knowledge and psychology caused inhibition in speaking performance among EFL students.

Obviously, speaking skill is not easy for EFL students. That is because of a variety of factors may affect them or prevent them from speaking such as grammar, vocabulary, comprehension, fluency and pronunciation. Students have to be aware of these components (Brown, 2004) if they want to speak English well. The findings of the study are also in line with that of Elia, Fitra \& Irianti, Dewi (2015) finding that lack of confidence might cause inhibition, and more dangerously, leading to a problem that some students do not believe in their own ability in speaking English. Consequently, they chose "silence" during a speaking class. It seems that those students who reported that they lacked vocabulary or confidence might not get much support from the teachers, which might negatively affect students' speaking skills. Another finding of the study was that most of the students reported that negative evaluation of the teacher also often caused inhibition in speaking among them. Obviously many students feared negative criticism from the teacher. This finding of the study is in alignment with those of other studies showing that negative criticism or evaluation from teachers or peers might prevent students from speaking (Al Hosni, 2014; Abedini \& Chalak, 2017). It is undeniable that if the teacher always tries to find out mistakes or errors and negative aspects of the students and then give negative comments on what the students have done, it can be affirmed that no students dare to say anything in class. Baker and Westrup (2003) stated that if the students are corrected all the time and with severe correction, they can find this very demotivating and become afraid to speak. Positive attitudes and effective ways of giving corrective feedback are a necessary and effective tool for an EFL teacher in the context like Vietnam.

Knowing what to do to reduce students' inhibition in speaking performance is always primary concern in foreign or second language learning. To reduce students' inhibition in speaking performance, it is necessary for both teachers and students themselves to take action in a number of ways. Different strategies should be employed by both of them. The findings of the study revealed that both teachers and students were aware of what should be done and what strategies were needed to reduce inhibition among students. The findings of the study may imply that both teachers and students need to play an active role.

Students want their teachers to apply a variety of teaching techniques to reduce their inhibition. This finding was similar to that of Liao's study (2000), revealing that a variety of classroom activities may help language students to foster themselves to communicate using the target language; meanwhile, teachers also want their students to apply different strategies and overcome difficulties in learning English. By doing so, they can help themselves complete language tasks more successfully ( $\mathrm{O}^{\text {ec Malley }}$ \& Chamot, 1990).

\section{CONCLUSION AND RECOMMENDATIONS}

The present study was conducted to explore factors causing inhibition in English speaking performance and strategies both teachers and students should employ to reduce students' inhibition. The focus of study was investigating factors related to students and teachers. The findings revealed that more factors related to students cause inhibition than those related to teachers. Regarding strategies, most of the students' proposals focused on teachers' teaching methods, ways of giving corrective feedback and attitudes towards students' knowledge and ability. Meanwhile, teachers' proposals focused on students' practice, attitudes and learning strategies. This study is significant for both EFL teachers and students at HUFI. Based on the findings, it is recommended that, for EFL teachers at HUFI, they should teach their students learning strategies including (1) memory strategies, (2) cognitive strategies, (3) compensation strategies, (4) affective strategies, (5) metacognitive strategies, and (6) social strategies (Oxford, 1990); they should know when to give feedback and how to comment properly apart from creating a friendly and positive manner in teaching is another crucial expectation. What is more, to help students become less anxious and more willing to speak the target language in English speaking classes, teachers need to create a relaxing and supportive classroom environment with a variety of relevant tasks or activities, encourage them to speak and help them 
establish positive attitudes towards learning. For EFL students, they need to be aware that a variety of factors may prevent them from speaking. To be confident in speaking English they need to take risk in learning, practice speaking with friends and teachers, communicate with foreigners outside the class; and especially, they need to employ different strategies both in learning speaking skill and communicating with others in English.

\section{REFERENCES}

[1] Abedini, F. \& Chalak, A. (2017) Investigating the inhibitive factors in the speaking of Iranian EFL learners. Journal of Applied Linguistics and Language Research, 4 (6), 82-97.

[2] Adam, M. A. A. (2016). Role of Vocabulary Learning Strategies in Promoting EFL Learners Performance (Doctoral dissertation, Sudan University of Science and Technology).

[3] Al Hosni. S. (2014). Speaking difficulties encountered by young EFL learners. International Journal on Studies in English Language and Literature (IJSELL. 2 (6), 22-30.

[4] Baker, J., \& Westrup, H. (2003).Essential speaking skills: A handbook for English language teachers. London: Continuum.

[5] Brown, H.D. (1994). Principles of language learning and teaching. New Jersey. Longman.

[6] Brown, H. D. (2000). Principles of language learning and teaching. New York: Longman.

[7] Brown, H. D. (2002). Principles of language learning and teaching. Beijing. Foreign Language Teaching and Research Press, 85-87.

[8] Brown, H. D. (2004). Language assessment: Principle and classroom practices. New York: Pearson Education.

[9] Brown, G., \& Yule, G. (1983).Teaching the spoken language. Sciences Journal17 (10): 1287-1297.

[10] Bygate, M. (1987). Speaking. Oxford: Oxford university press.

[11] Cohen, N. J. (2001). Language impairment and psychopathology in infants, children, and adolescents. New York: Sage Publications.

[12] Cook, V. (2013). Second language learning and language teaching. New York: Routledge.

[13] Dörnyei, Z., \& Chan, L. (2013). Motivation and vision: An analysis of future L2 self images, sensory styles, and imagery capacity across two target languages. Language learning, 63(3), 437-462.

[14] Dornyei, Z., \& Kubanyiova, M. (2014). Motivating learners, motivating teachers. Cambridge: Cambridge University Press.

[15] Elia, F., \& Irianti, D. (2015). Psychological factors that hinder students from speaking in English. Journal of English for Academic, 2(2), 50-61.

[16] Kelly, G. (2000). How to Teach Pronunciation. New York: Pearson Education India.

[17] Kubo, M. (2009). Extensive pair taping for college students in Japan: Action research in confidence and fluency building. Accents Asia, 3(1), 36-68.

[18] Lightbown, P. M. (2003). SLA research in the classroom/SLA research for the classroom. Language Learning Journal, 28(1), 4-13.

[19] Liao, X. Q. (2000). Communicative language teaching innovation in China: Difficulties and solution. Retrieved from http://eric.ed.gov/PDFS/ED443294.pdf.

[20] O"Malley, J. M. \& Chamot, A. U. (1990). Learning strategies in second language acquisition. Cambridge: Cambridge University Press.

[21] Oxford, R. L. (1990). Language learning strategies: What every teacher should know. New York: Newbury House.

[22] Oxford, R. L. (2003). Language learning styles and strategies: Concepts and relationships. Iral, 41(4), 271278.

[23] Richards, J. C., \& Schmidt, R. (2002). Longman dictionary of applied linguistics and language teaching. Harlow, UK: Longman.

[24] Schmitt, N. (2010). Researching vocabulary: A vocabulary research manual. New York: Macmillan.

[25] Spielberger, C. D. (Ed.). (2013). Anxiety: Current trends in theory and research. New York: Elsevier.

[26] Truscott, J., \& Hsu, A. Y. P. (2008). Error correction, revision, and learning. Journal of second language writing, 17(4), 292-305. 


\section{AUTHOR'S BIOGRAPHY}

Tran Thị Trang Loan, English lecturer at Ho Chi Minh City University of Food Industry (HUFI)Vietnam

Le Van Tuyen, English lecturer at Ho Chi Minh City University of Technology (HUTECH)-Vietnam

Citation: Tran Thi Trang Loan, Le Van Tuyen. "Factors Causing students' Inhibition in English Speaking Performance. "International Journal on Studies in English Language and Literature (IJSELL), vol 8, no. 4, 2020, pp. 1-10. doi: http://dx.doi.org/10.20431/2347-3134.0804001.

Copyright: () 2020 Authors. This is an open-access article distributed under the terms of the Creative Commons Attribution License, which permits unrestricted use, distribution, and reproduction in any medium, provided the original author and source are credited. 